\title{
Delayed Senescence in Soybean: Terminology, Research Update, and Survey Results from Growers
}

\author{
C. J. Harbach, University of Illinois, Urbana 61801; T. W. Allen, Mississippi State University, Delta Research and Extension Center, \\ Stoneville 38776; C. R. Bowen, USDA-ARS, University of Illinois, Urbana 61801; J. A. Davis, Louisiana State University Agricultural \\ Center, Baton Rouge 70803; C. B. Hill, University of Illinois, Urbana 61801; M. Leitman, United Soybean Board and SmithBucklin, \\ Chesterfield, MO 63017; B. R. Leonard, Louisiana State University Agricultural Center, Baton Rouge 70803; D. S. Mueller, Iowa State \\ University, Ames 50011; G. B. Padgett, Louisiana State University Agricultural Center, Baton Rouge 70803; X. A. Phillips, Iowa State \\ University, Ames 50011; R. W. Schneider, Louisiana State University Agricultural Center, Baton Rouge 70803; E. J. Sikora, Alabama \\ Cooperative Extension System, Auburn University 36849; A. K. Singh, Iowa State University, Ames 50011; and G. L. Hartman, USDA- \\ ARS, University of Illinois, Urbana 61801
}

Accepted for publication 23 March 2016. Published 15 April 2016.

\section{ABSTRACT}

Harbach, C. J., Allen, T. W., Bowen, C. R., Davis, J. A., Hill, C. B., Leitman, M., Leonard, B. R., Mueller, D. S., Padgett, G. B., Phillips, X. A., Schneider, R. W., Sikora, E. J., Singh, A. K., and Hartman, G. L. 2016. Delayed senescence in soybean: Terminology, research update, and survey results from growers. Plant Health Prog. 17:76-83.

The terms used to describe symptoms of delayed senescence in soybean often are used inconsistently or interchangeably and do not adequately distinguish the observed symptoms in the field. Various causes have been proposed to explain the development of delayed senescence symptoms. In this article, we review published reports on delayed senescence symptoms in soybean, summarize current research findings, provide examples of terms related to specific symptoms, and present an overview of the results of a multi-state survey directed to soybean growers to understand their concerns about delayed soybean senescence. Some of these terms, such as green bean syndrome and green stem syndrome, describe symptoms induced by biotic factors, while other terms describe symptoms associated with abiotic factors. Some delayed senescence terms involve the whole plant remaining green while other terms include just the stem and other plant parts such as pods. In the grower survey, $77 \%$ reported observing soybean plants or plant parts that remained green after most plants in the field were fully mature with ripe seed. Most respondents attributed these symptoms to changes in breeding and choice of cultivars. At the end of this article, we standardized the terms used to describe delayed senescence in soybean.

\section{INTRODUCTION}

Terminology associated with the delayed senescence of stems, leaves, pods, and seeds or various combinations of affected organs in field-grown soybean include delayed stem senescence, green bean syndrome, green plant malady, green stem, green stem disorder, green stem malady, green stem syndrome, greening effect, and stay-green. In general, these terms often do not adequately describe the associated symptoms. As a result, scientific articles and agricultural press releases often use various terms inconsistently or interchangeably to describe delayed senescence in soybean. Presently, a limited number of studies have used specific treatments (e.g., fungicides, herbicides, insecticides and/or water deficits, and pathogen or pest inoculations) in attempts to re-create the symptoms associated with delayed senescence. The purpose of this article is to: (i) review the literature used to describe delayed senescence symptoms; (ii) present the results of a multi-state survey that asked soybean growers and crop advisors about their views on delayed senescence, (iii) provide a brief summary of recent research; and (iv) define terms recommended for use to describe different symptoms associated with delayed soybean senescence.

Corresponding author: Glen L. Hartman. Email: ghartman@illinois.edu.
In soybean, of the various terms used to explain delayed senescence, the main characteristic is the occurrence of green stems (Fig. 1). Green stems at senescence may be accompanied by other plant parts (leaves, petioles, pods, and seeds) remaining immature. Green-stemmed plants may have normal or fewer pods that may or may not remain green. Several factors proposed as possible causes of delayed plant senescence include: abiotic factors caused by environmental stresses and pesticide applications; or by biotic causes including feeding from the bean leaf beetle (Cerotoma trifurcata Forster) and stink bug (Pentatomidae), and/or infection by Bean pod mottle virus (BPMV), phytoplasmas, and Soybean mosaic virus (SMV); or by interactions of abiotic and biotic factors, the environment, and host genetics.

There is no clear documentation on when delayed senescence was first described in soybean, or if it has increased over the past few decades. Perhaps one of the first pictures of delayed senescence due to an unknown cause was captured in the 1950s when plants with green stems at pod or seed maturity were photographed in a field (Fig. 2; Craig Grau, personal communication). The following seven sections review, in alphabetic order, the names or terms and their definitions used in published literature that describe delayed senescence in soybean. 


\section{GREEN BEAN SYNDROME}

Green bean syndrome has been the term used primarily in the southern United States for the condition in which the maturity of the whole plant is delayed, including the pods (Greene and Davis 2015). Early work evaluated the role of insect attack (Boethel et al. 2000; Daugherty et al. 1964), although at that time green bean syndrome was not widespread and thus not an overall yield constraint. Nevertheless, these studies documented that stink bug injury disrupted normal plant maturation processes. For example, under extreme stink bug pressure, green bean syndrome can be associated with delayed maturity. In this case, pods, leaves, and stems remain green and plants cannot be efficiently harvested unless a harvest aid like paraquat (Gramoxone, Syngenta Crop

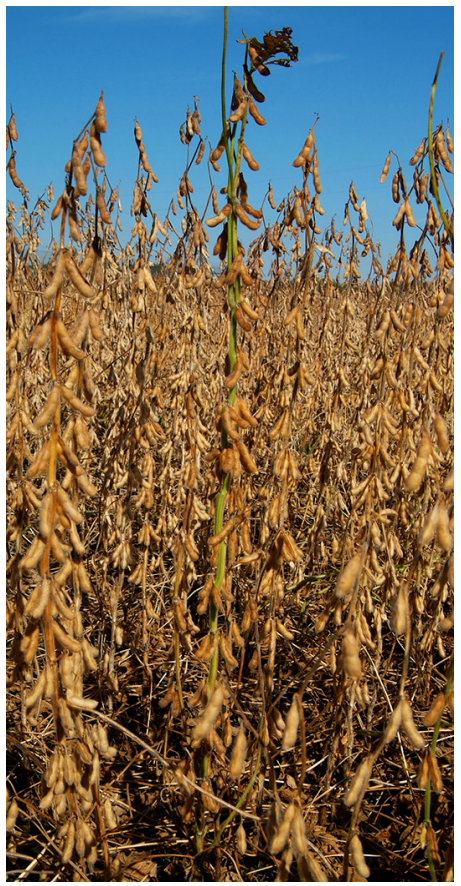

\section{FIGURE 1}

A soybean plant exhibiting green stem disorder (center), while neighboring plants senesced and are ready to harvest.

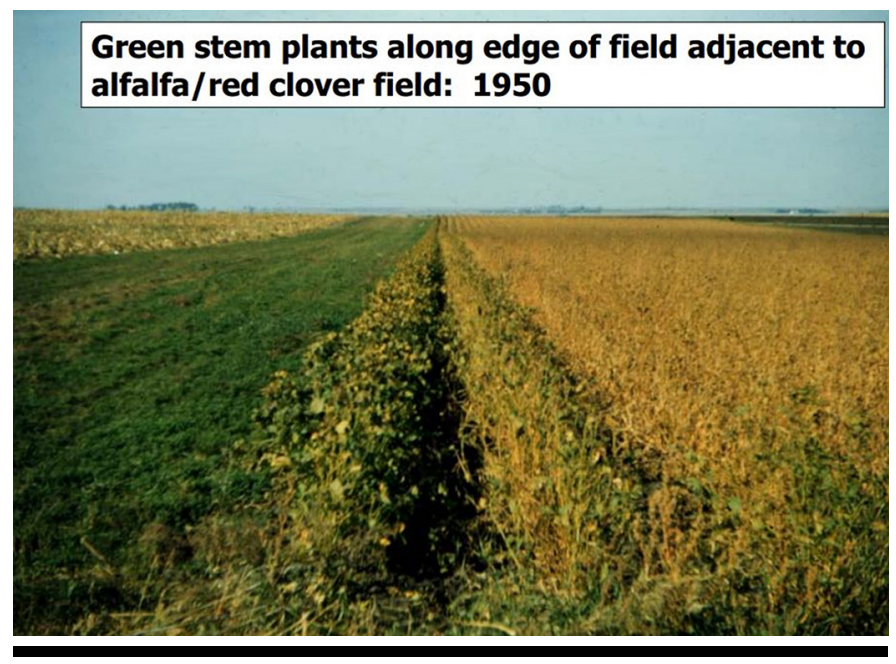

FIGURE 2

In 1950, a soybean field that has plants with green stems, bordering an alfalfa/red clover field.
Protection, Greensboro, NC) is applied to reduce moisture in leaves, pods, and stems. Even after an application of the harvest aid, seeds within pods on affected plants may remain immature and seed moisture levels remain excessively high. This produces the symptom of "green beans" (i.e., green seed) that occur in post-harvest seed samples (Fig. 3). Though this condition is often associated with stink bug (various genera in Pentatomidae) feeding, other associations have been implicated, including Rhizoctonia aerial blight (Rhizoctonia solani), Cercospora leaf blight (Cercospora kikuchii), and mycoplasmas transmitted by the potato leafhopper (Empoasca fabae). In some cases, bud proliferation is common and associated with the potato leafhopper (Dale and Walters 1985). Yields are often compromised through pod reductions (fewer and smaller) and reduced seed quality.

\section{GREEN PLANT (OR STEM) MALADY}

Green plant malady symptoms often include green leaf retention, green stems, and delays in seed maturation resulting in poor seed quality. Field studies at several locations in Louisiana were designed to determine if green plant malady (also referred to as green stem) incidence was related to cultivars, insect injury, the fungicide pyraclostrobin (Headline, BASF, Inc., Florham Park, $\mathrm{NJ}$ ), the herbicide glyphosate (Roundup, Monsanto, Inc., St. Louis, MO), water deficits, or their interactions (Leonard et al. 2011). The primary determinant of green plant malady in these studies was cultivar (Fig. 4). The other major contributing factors were insects (primarily stink bug damage) and the application of pyraclostrobin. In some but not all cultivars, there were highly significant interactions among water deficits, pyraclostrobin, and glyphosate. However, the glyphosate-water deficit interaction was inconsistent and not observed at all locations. The location effect was likely related to differences in evaporative demand, other environmental determinants, and stink bug infestation levels among locations. There was no interaction between pyraclostrobin and glyphosate, and none of the common soybean viruses appeared to be associated with the incidence of green plant malady (Leonard et al. 2011; Schneider et al. 2010). Along with green stem symptoms, some cultivars also displayed green

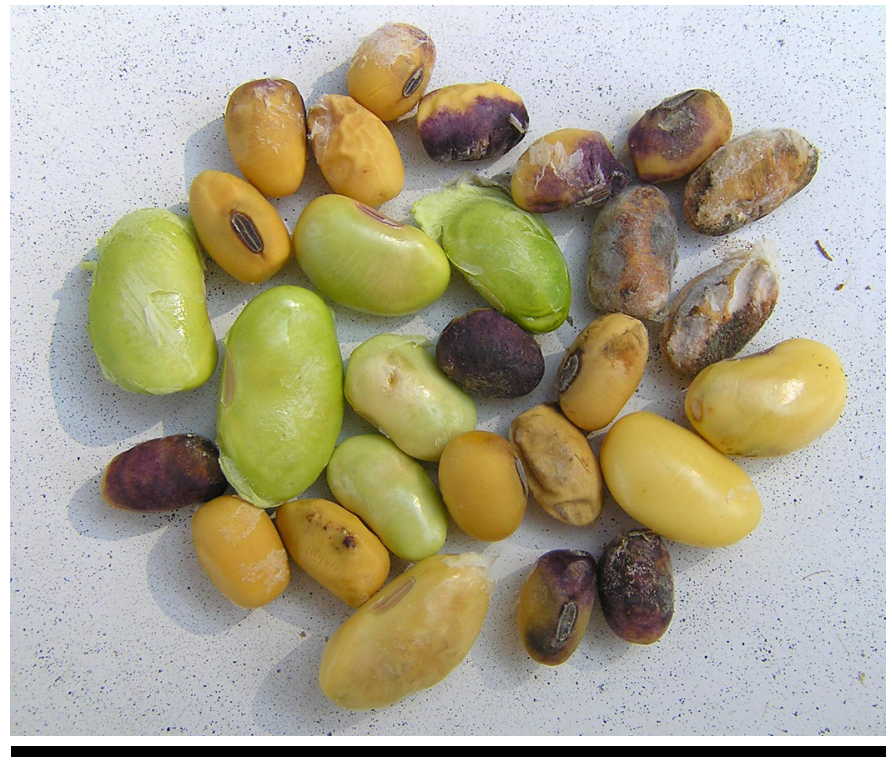

FIGURE 3

Damaged and discolored seeds harvested from green stem-affected soybean plants. Notice that some seeds remained green and did not mature. Other seeds show symptoms of purple seed stain, caused by Cercospora kikuchii, and damage attributed to stink bug feeding. 
leaf retention (Fig. 5) with some cultivars displaying "green bean effect" in which seeds did not mature (remained green) or were misshapen (Fig. 3) (Padgett et al. 2010). However, the primary symptom across all locations, treatments, and cultivars was stems remaining green while pods matured. Furthermore, applications of paraquat, normally applied as a harvest aid at physiological maturity in order to hasten senescence, were shown to be relatively ineffective when applied to green stem-affected fields (Boudreaux and Griffin 2011; Boudreaux et al. 2010).

\section{GREEN STEM}

The term green stem has been generally used and refers to plants with nonsenescent stems, and has been used as a catchall term for delayed senescence because it also refers to plants with or without leaves attached, pods turning brown or remaining green, and may or may not be associated with yield loss.

\section{GREEN STEM DISORDER}

This term was first used in 2006 in a study conducted in Illinois and Wisconsin and was defined as plants with non-senescent stems mostly with petioles not attached but with normal, mature pods and seeds at harvest maturity (Fig. 6) (Hobbs et al. 2006). In addition, this study determined that green stem disorder was not

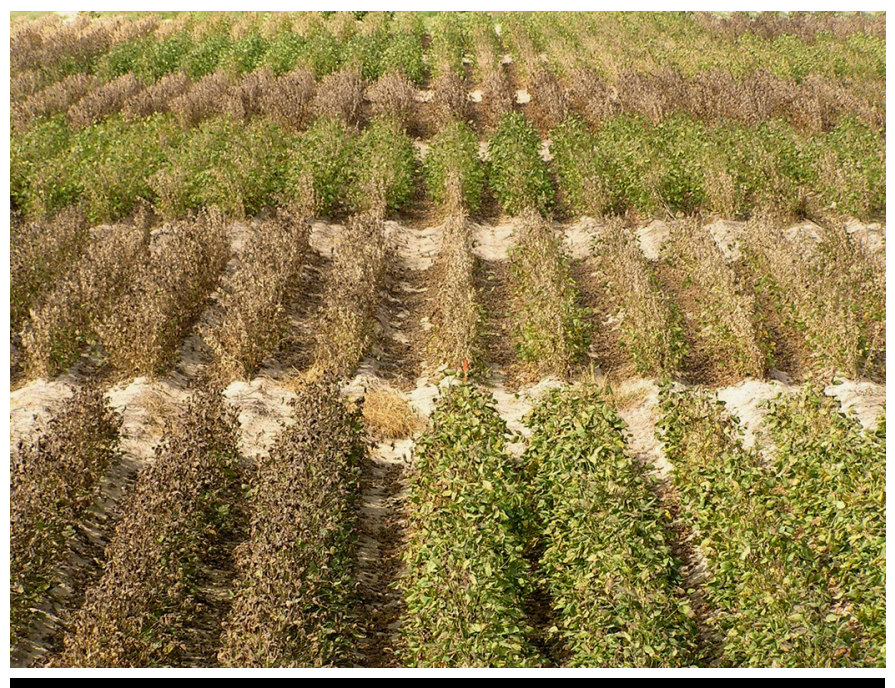

FIGURE 4

Field plots of soybean cultivars showing differences in senescence based on fungicide, herbicide, and water deficit treatments.

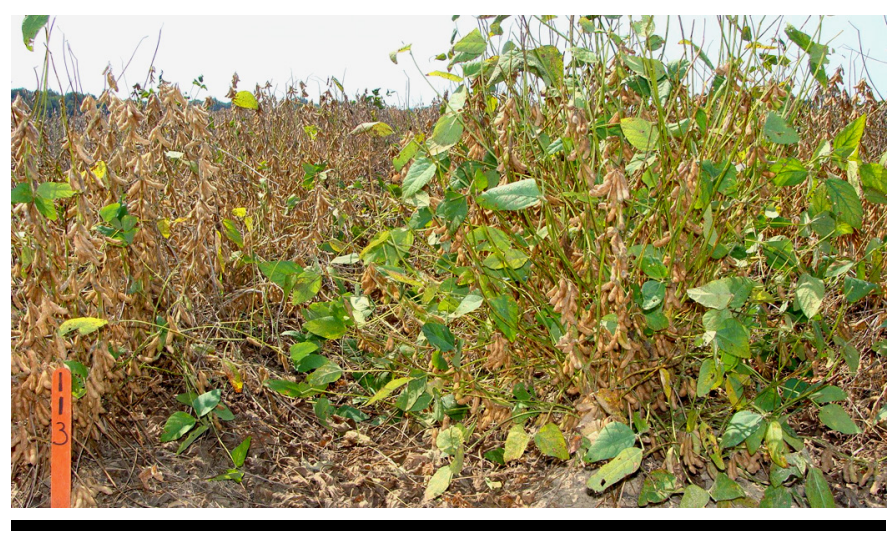

FIGURE 5

Delayed senescence of soybean with plants showing leaf retention (right). Notice that pods are mature and ready to be harvested. associated with BPMV infection or feeding from bean leaf beetles, leaf hoppers, or stink bugs (Hobbs et al. 2006). In a study from Argentina, green stem disorder was reported to be independent of Alfalfa mosaic virus (AMV), Bean common mosaic virus (BCMV), BPMV, SMV, Tobacco ringspot virus (TRSV), and Tobacco streak virus (TSV) (Formento and de Souza 2009). Soybean plants with green stem disorder symptoms were reported to have stems with fewer fungal pathogens than normal stems (Fig. 7; Hill et al. 2006), suggesting that the lack of fungal parasitism may be associated with the disorder.

Variability in sensitivity to green stem disorder among soybean cultivars also was reported. It was suggested the disorder could be managed through cultivar selection (Hill et al. 2006). In addition, fungicide applications were shown to increase the incidence of green stem disorder, especially in green stem disorder-sensitive

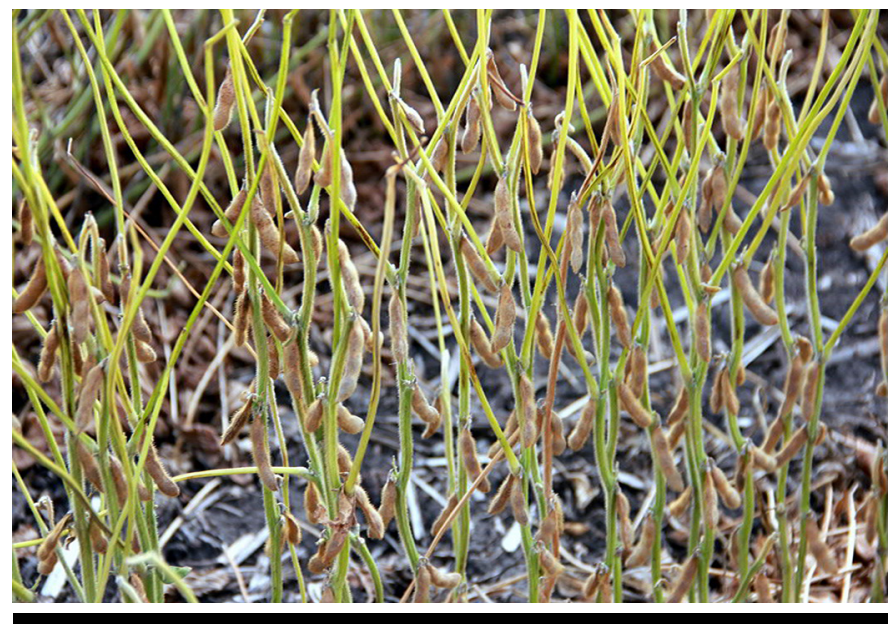

FIGURE 6

Soybean plants with green stems and mature pods with normal pod fill, symptomatic of green stem disorder.

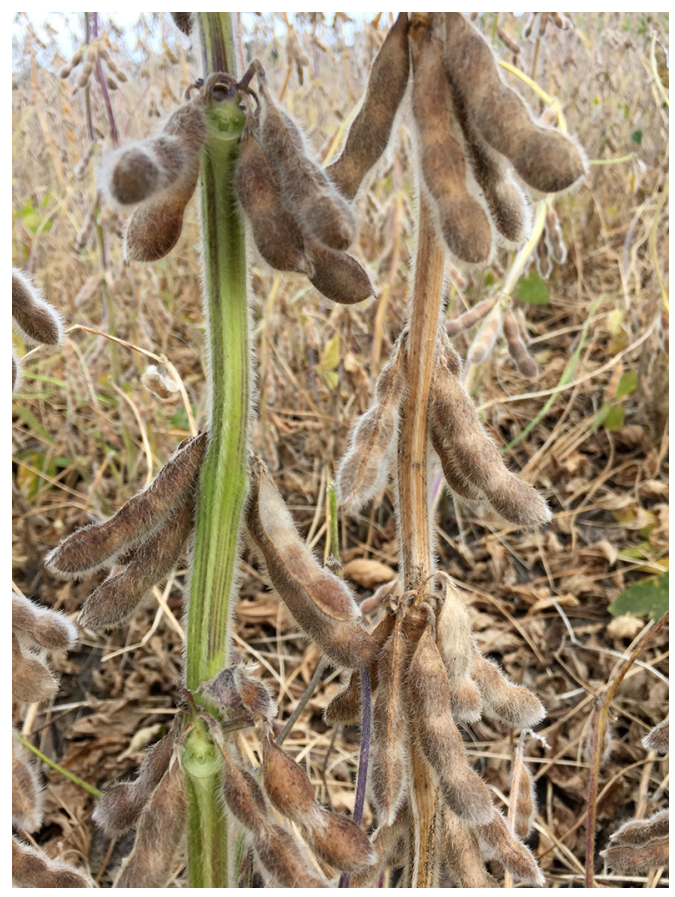

FIGURE 7

Normal, fully mature pods on green a green soybean stem (left), characteristic of green stem disorder, and a fully mature stem (right). 
soybean cultivars (Hill et al. 2013). More specifically, when soybean plants were sprayed at different times during selected reproductive growth stages (Fehr et al. 1971), a strobilurin fungicide increased green stem disorder incidence more than a triazole fungicide, although the incidence varied depending on location and cultivar (Hill et al. 2013).

Green stem disorder did not reduce soybean yields based on data collected from 1,090 soybean cultivars at seven locations in Illinois from 2009 to 2012 (Table 1). These results indicated that there was no correlation with the incidence of green stem disorder and yield. Green stem disorder in Japan, also called delayed stem senescence (Isobe et al. 2014; Mochizuki et al. 2005; Sato et al. 2007; Yamada et al. 2014), also was reported to be dependent on soybean genotype and independent of yield (Isobe et al. 2014). Researchers in Japan identified three major quantitative trait loci (QTLs) associated with green stem disorder insensitivity, which they measured as the "degree of synchronous senescence," of which only one QTL was detected in the vicinity of a maturity gene (Yamada et al. 2014). Discovery of these QTLs can aid soybean breeders through the use of marker-assisted breeding, which can lead to cultivars that are less sensitive to green stem disorder. Future efforts should determine linkage drag or pleiotropic effects of green stem disorder QTLs, as qGSDI on linkage group $\mathrm{H}$ also is associated with shorter seed filling period and lower protein (Yamada et al. 2014). The effect of growth habit on green stem disorder remains unresolved; however, early flowering genotypes appeared to be more sensitive (Fujii et al. 2015).

\section{GREEN STEM SYNDROME}

The term green stem syndrome in soybean was used in a report published in 1980 to describe plants with green stems at maturity in Kansas (Schwenk and Nickell 1980). The plants identified as having green stem syndrome had delayed stem maturity,

\begin{tabular}{|c|c|c|c|}
\hline \multicolumn{4}{|c|}{$\begin{array}{l}\text { TABLE } 1 \\
\text { Pearson correlation coefficients for green stem disorder } \\
\text { incidence with yield based on University of Illinois } \\
\text { Soybean Variety Testing locations throughout Illinois. }\end{array}$} \\
\hline Year & Location ${ }^{a}$ & $n^{\mathbf{b}}$ & $r^{c}$ \\
\hline 2009 & Goodfield & 808 & 0.08 \\
\hline 2009 & Monmouth & 857 & $0.28 * * *$ \\
\hline 2009 & New Berlin & 138 & -0.05 \\
\hline 2009 & Perry & 684 & $0.11 * *$ \\
\hline 2010 & Dwight & 677 & $0.20 * * *$ \\
\hline 2010 & Goodfield & 676 & $0.21 * * *$ \\
\hline 2010 & Monmouth & 678 & $0.34 * * *$ \\
\hline 2010 & New Berlin & 753 & $-0.11 * *$ \\
\hline 2010 & Perry & 745 & $0.28 * * *$ \\
\hline 2010 & Urbana & 945 & $-0.09 * *$ \\
\hline 2011 & Monmouth & 678 & $-0.09 *$ \\
\hline 2011 & New Berlin & 711 & $-0.13 * * *$ \\
\hline 2011 & Urbana & 711 & 0.00 \\
\hline 2012 & Dwight & 726 & $-0.09 *$ \\
\hline 2012 & Elkville & 402 & $-0.28 * * *$ \\
\hline 2012 & Goodfield & 726 & $-0.12 * *$ \\
\hline 2012 & New Berlin & 753 & -0.02 \\
\hline 2012 & Perry & 753 & $0.23 * * *$ \\
\hline 2012 & Urbana & 753 & 0.00 \\
\hline
\end{tabular}

${ }^{a}$ Locations included maturity groups II-V and both glyphosate-tolerant and conventional soybeans.

$\mathrm{b}$ Total number of plot observations.

${ }^{\mathrm{c}}$ Significant correlation coefficients: $*=P \leq 0.05 ; * *=P \leq 0.01$; and $* * *=P \leq 0.001$ nonsenescent petioles, and had fewer pods per node that were thinner, brown, or mature, with dried, small seed (Fig. 8). BPMV was implicated as the main cause of green stem syndrome (Schwenk and Nickell 1980). The term green stem syndrome also was used in Virginia and referred to plants that had green stems and often had reduced yield associated with plant stress during pod and seed development (Holshouser 2009). In addition, even though the incidence of mottled seed and green stem syndrome were low in the presence of TSV, a $25 \%$ grain yield reduction was reported primarily due to plant mortality caused the virus (Rabedeaux et al. 2005). It appears that the virus can cause sterility and the entire plant remains green after harvest (Fig. 8), or plants may appear to yield normally but remain green often times with leaves attached (Fig. 9).

In Kentucky, researchers reported that by removing soybean pods at pod fill (growth stage R6), soybean stems remained green longer than the stems of the control plants, and this difference was independent of the cultivar tested (Egli and Bruening 2006). They showed that green stems had higher concentrations of soluble sugars, starch, and nitrogen, suggesting that green stems were a result of moisture from roots and photosynthates from leaves in response to the development of replacement pods.

\section{GREENING EFFECT}

The term greening effect has been associated with the use of strobilurin foliar fungicides (Bartlett et al. 2002), which delays the natural aging process in plants causing them to maintain green leaf area longer; once the plant has reached full maturity, it dries down normally. This term was used to explain the situation in wheat when green leaf area extended the grain filling period resulting in higher yields with an application of a strobilurin (Bartlett et al. 2002). Although greening effect may be similar to green stem disorder, there are differences. In general, plants with green stem disorder do not characteristically retain leaves and do not delay pod and seed maturity as pods and seeds dry down normally even though the stems remain green.

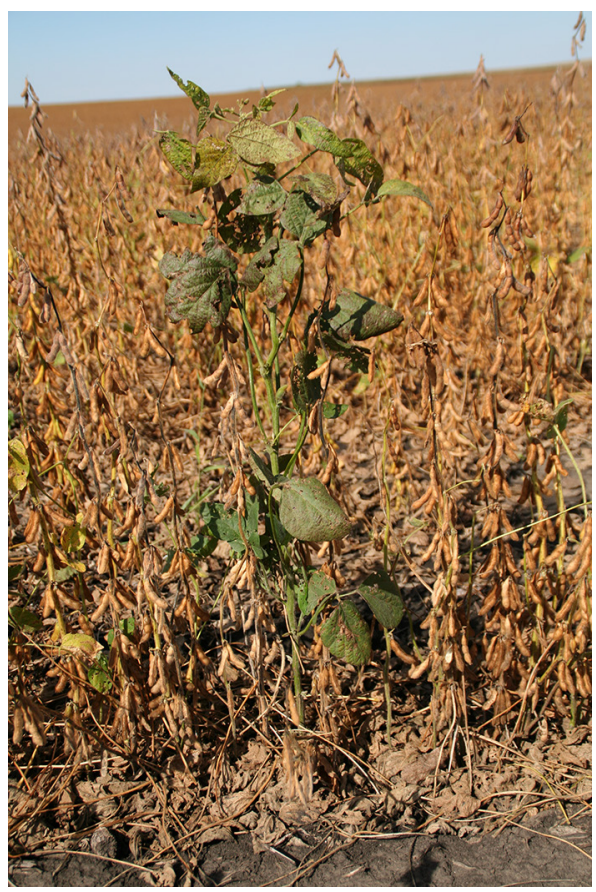

FIGURE 8

A soybean plant displaying green stem syndrome with no pods. 


\section{STAY-GREEN}

The term stay-green has not been widely used in soybean, but it has been commonly used in other crops including maize and sorghum. In these crops, the leaves and stalks often remain green through harvest, often resulting in healthier stems and higher yields (Thomas and Ougham 2014). Also, QTLs that control the stay-green trait in maize were mapped, and marker-assisted selection was used in breeding programs to select plants for staygreen genes (Wang et al. 2012). Along with yield, stay-green increased drought tolerance in cowpea (Gwathmey and Hall 1992) and sorghum (Borrell et al. 2014).

In soybean, as in other crops displaying the stay-green trait, yield is often associated with duration of the seed-filling period and extending that period often leads to higher yields (Kumudini et al. 2007). Soybean plants with stay-green symptoms often retain their leaves and all above-ground plant remains green longer than normal. The stay-green trait in soybeans has been shown to be associated with recessive mutations of the determinant genes $d 1$ and $d 2$, which together cause retention of chlorophyll, their binding proteins, and higher levels of rubisco in leaves (Luquez and Guiamet 2000).
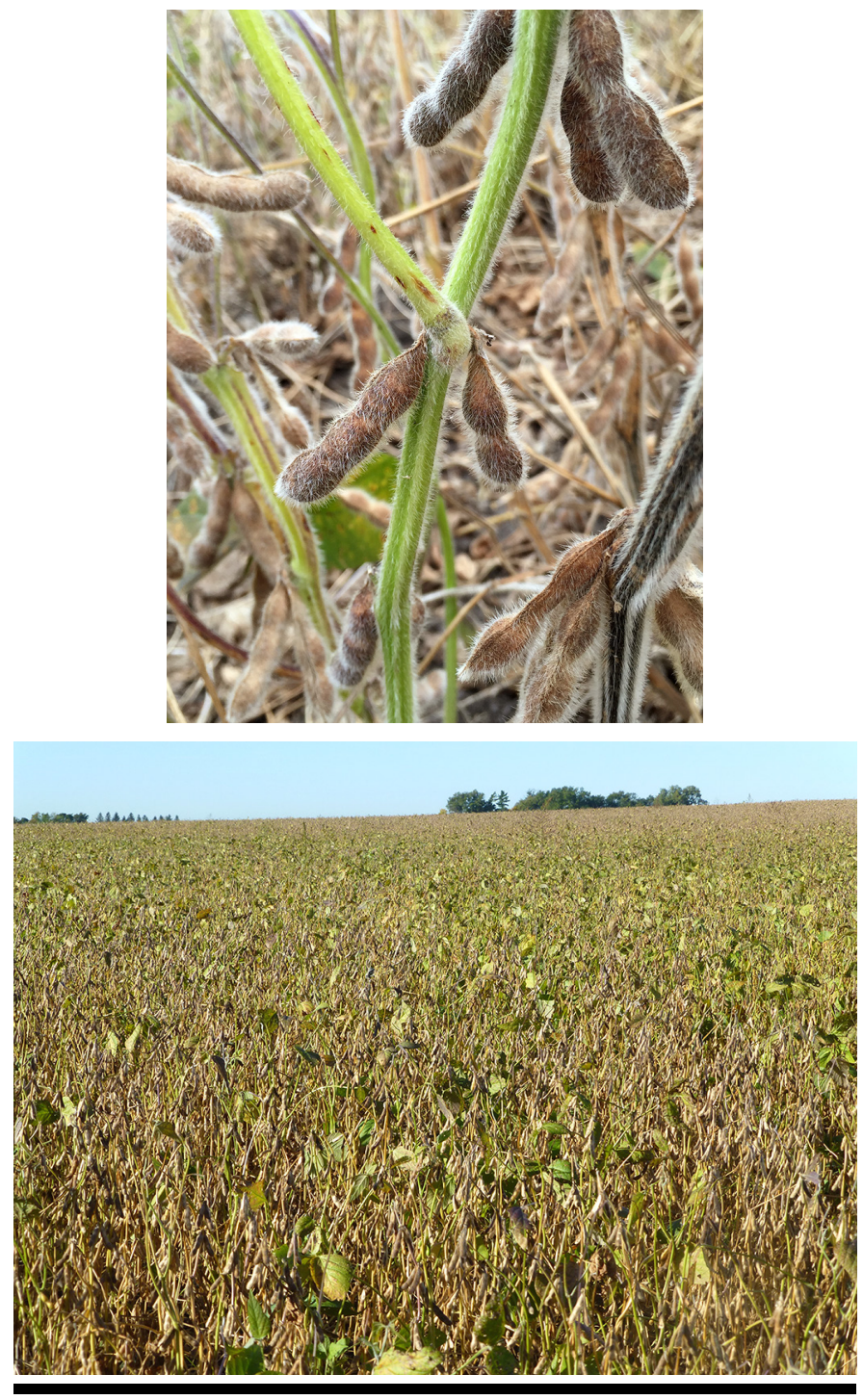

FIGURE 9

Tobacco streak virus may cause "green soybean syndrome" on single plants (see Fig. 8), or plants may appear to yield normal but remain green often times with leaves attached (top and bottom).

\section{4/2015 GROWER SURVEY}

In a survey supported by the United Soybean Board, growers and crop advisors were asked a series of questions related to delayed senescence in soybeans. Survey results from four northcentral states (Illinois, Indiana, Iowa, and Wisconsin) and six southern states (Alabama, Kentucky, Mississippi, North Carolina, South Carolina, and Tennessee) were collected and tabulated in 2015.

Of 76 respondents, $77 \%$ reported observing soybean plants or plant parts in their fields that remained green beyond a normal harvest date (Table 2). Of those observing these symptoms, 95\% reported harvest delays, $53 \%$ applied a production practice to alleviate the harvest delay, and the percent of acreage affected averaged $43 \%$ (Table 2). The term most frequently used to describe symptoms of delayed maturity in soybean was green stem $(72 \%)$, followed by green bean syndrome (13\%), green stem syndrome (10\%), and green stem disorder (2\%) (Fig. 10). In order to combat harvest delays, $34 \%$ of the respondents used a harvest aid (i.e., paraquat) while 33\% reported doing nothing (Fig. 11). Other management practices employed included fungicide applications $(27 \%)$, insecticide applications (12\%), cultivar selection (10\%), stress prevention (4\%), and planting date management (3\%) (Fig. 11). Most respondents attributed these symptoms to changes in breeding and choice of cultivar $(29 \%)$ (Fig. 12). Insect damage, the use of strobilurin fungicides, and changes in weather patterns also were listed as suspected causes of delayed maturity (Fig. 12).

\section{FURTHER CONSIDERATIONS}

Delayed stem senescence of soybean refers to the persistence of green stems at crop maturity (growth stage R8), which makes the crop more difficult to combine. As a result, fields with high incidences of delayed stem senescence may require combine operators to reduce ground speed and increase engine power, resulting in poor fuel efficiency and increased harvest time, and increase wear and tear on combines. Furthermore, many growers (primarily in the southern production region) resort to harvest aids to help reduce moisture associated with green stems and leaf

TABLE 2
Summary of "yes" responses (in percentages) from growers
and industry advisors to survey questions about delayed
maturity symptoms (plants remain green beyond normal
harvest date) in soybean in the USA.


tissue as a result of delayed senescence. Even with harvest aid applications, harvest cannot commence until the pre-harvest interval for the specific pesticide has been exceeded. A delay in harvest often increases the vulnerability to such factors as lodging, shattering, and seed decay that can reduce grain yield and/or quality. In addition, moisture in the seed may not be reduced, especially when insect damage is a contributing factor to delayed stem senescence.

Management options may vary depending upon the type of delayed senescence symptoms observed in the field. For example, growers that encounter green stem disorder, which does not appear to be yield limiting, may consider selecting insensitive soybean cultivars to manage the problem. Applications of a harvest aid at physiological maturity may hasten senescence. However, these applications can be relatively ineffective when applied to green stem-affected fields (Boudreaux et al. 2011; Boudreaux et al. 2010). Research in Brazil showed that applications of cobalt, molybdenum, and a seed inoculant, increased leaf nitrogen and corresponded to a decrease in green stem syndrome (Favero and Lana 2014). Other management options might include waiting past normal harvest time for the plants to senesce (some locations it may be a frost) or changing fungicides when yields are threatened.

Based on our survey results, farmers do not make a distinction between these maladies, and mostly refer to any delayed senescence symptoms as "green stem," which indicates that more outreach is required to educate growers on current scientific knowledge of the problem with less reliance on anecdotal evidence. Additionally, it is important for researchers to continue to make distinctions among different delayed maturity maladies to minimize confusion that can be generated by using different terms synonymously. Scientists continue to investigate the underlying genetic components of green stem disorder and how it relates to other agronomic traits. Entomologists and plant pathologists should continue to define those instances where pests (insects and diseases) and associated pesticide applications contribute to this symptomology, especially when seed yield and quality are compromised. In general, more research is needed to fully understand these various delayed maturity maladies to aid in development of soybean cultivars insensitive to delayed senescence and other effective and economical management practices.

Also, in order to develop soybean cultivars that are insensitive to delayed senescence in one or more aboveground organs, the physiological and biochemical mechanisms involved must be further understood to provide information on modes of action. For example, glyphosate may be involved in delayed senescence when used off label (high rates or later in the season) or on some specific soybean cultivars. Glyphosate is known to inhibit 5enolpyruvylshikimate-3-phosphate synthase (EPSPS), which is a key enzyme in the shikimate biosynthetic pathway and accounts for the production of aromatic amino acids, auxin, and many other secondary metabolites (Shaner 2006). It is now known that there is crosstalk between the signaling pathways for auxin and abscisic acid (ABA), and ABA has long been known to be involved in plant responses to water stress and senescence in soybean (Rock and Sun 2006; Samet and Sinclair 1980). While a detailed review of plant growth regulators is beyond the scope of this article, it is possible that biotic factors like pathogens and pests, and abiotic factors like herbicide and water stress interact and affect growth regulation in the plant, causing some form of delayed maturity.

\section{TERMINOLOGY}

Although there are clearly different factors involved in delayed senescence, there is still a need to differentiate and agree upon terminology of the symptoms observed. To clarify the condition of delayed senescence, we suggest using green soybean syndrome, green stem disorder, and greening effect to group

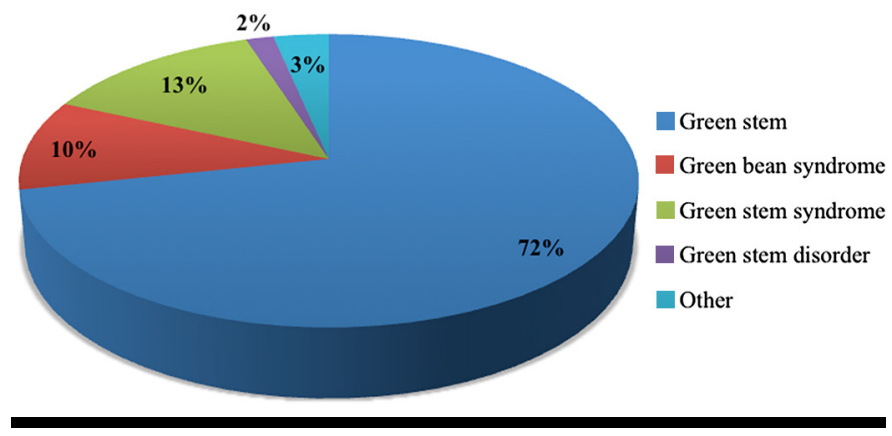

\section{FIGURE 10}

Frequency of terms used by soybean growers and crop advisors to describe delayed maturity symptoms in soybeans, based on a United Soybean Board survey (responses from Alabama, Illinois, Indiana, lowa, Kentucky, Mississippi, South Carolina, Tennessee, and Wisconsin).

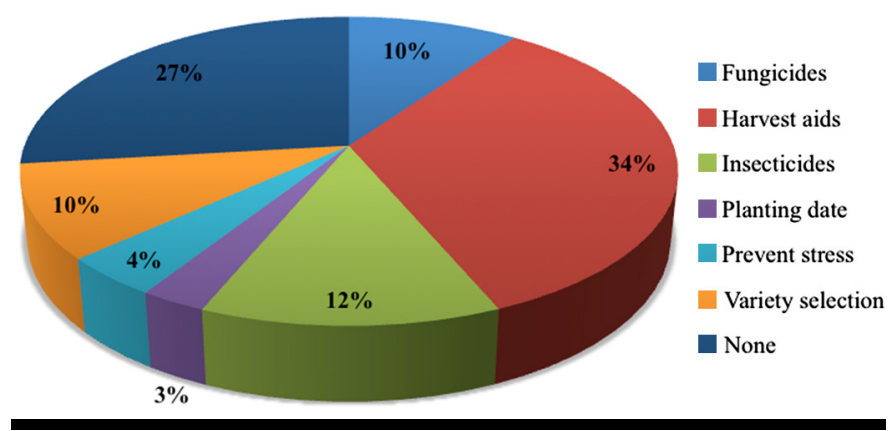

\section{FIGURE 11}

Frequency of production practices employed by growers to help prevent or alleviate delayed maturity symptoms in soybeans, based on a United Soybean Board survey (responses from Alabama, Illinois, Indiana, lowa, Kentucky, Mississippi, South Carolina, Tennessee, and Wisconsin.

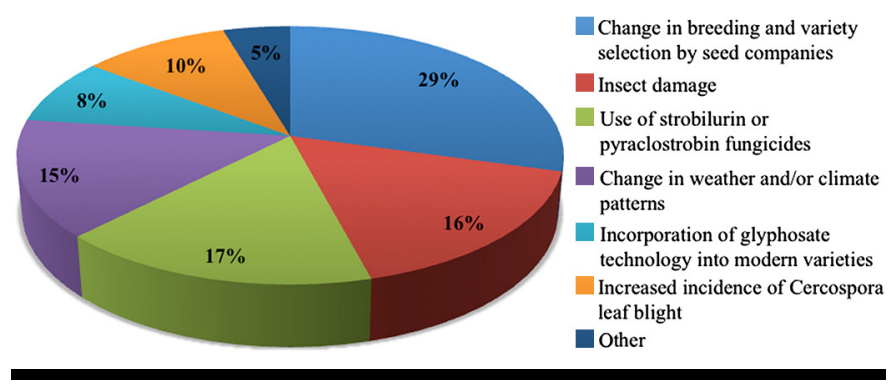

\section{FIGURE 12}

Frequency of what soybean growers and crop advisors think is the leading cause of increased incidence of delayed maturity in soybean, based on a United Soybean Board survey (responses from Alabama, Illinois, Indiana, lowa, Kentucky, Mississippi, South Carolina, Tennessee, and Wisconsin). 


\begin{tabular}{|c|c|c|}
\hline \multicolumn{3}{|c|}{$\begin{array}{c}\text { TABLE } 3 \\
\text { Suggested terms to define delayed senescence symptoms in soybeans. }\end{array}$} \\
\hline Term & Symptoms & Comments \\
\hline $\begin{array}{l}\text { Greening } \\
\text { effect }^{c}\end{array}$ & $\begin{array}{l}\text { Retention of leaves, petioles, pods, and stems } \\
\text { temporarily beyond expected maturity date. }\end{array}$ & $\begin{array}{l}\text { Often associated with pesticide applications characterized by extended } \\
\text { retention of leaves beyond normal maturity. If prolonging maturity is } \\
\text { not desired, careful selection of pesticides may be needed. }\end{array}$ \\
\hline
\end{tabular}

\footnotetext{
${ }^{a}$ This is a new term; includes the terms green plant malady, green stem malady, green bean syndrome, and green stem syndrome. This term usually represents an obvious detriment to yield.

${ }^{\mathrm{b}}$ Seed yields are often reported to be normal.

${ }^{\mathrm{c}}$ Includes the term stay-green, a genetically controlled trait that has similar symptoms to greening effect, but is not a widely used trait in soybean.
}

similar symptoms and observed effect on soybean plants (Table 3). Plants with green soybean syndrome often suffer obvious yield loss caused by known or unknown biotic factors, usually through insect damage and through the transmission of phytoplasmas or viruses. Plants with green stem disorder are fully mature except for the green or sometimes purple stems. Plants with greening effect remain green and continue to be entirely green beyond the date of normal maturity. As research continues, these terms will provide the basis to understand the different outcomes and causes of delayed senescence in soybean. Additional studies are needed to determine the cause of these various types of delayed senescence symptoms, which will in turn provide growers with information including potential management schemes to address delayed senescence symptoms in soybean.

\section{ACKNOWLEDGMENTS}

We thank the Illinois Soybean Association and the United Soybean Board for partial financial and grower survey support.

\section{LITERATURE CITED}

Bartlett, D. W., Clough, J. M., Goodwin, J. R., Hall, A. A., Hamer, M., and Parr-Dobrzanski, B. 2002. The strobilurin fungicides. Pest. Manag. Sci. 58:649-662.

Boethel, D. J., Russin, J. R., Wier, A. T., Layton, M. B., Mink, J. S., and Boyd, M. C. 2000. Delayed maturity associated with southern green stink bug (Heteroptera: Pentatomidae) injury at various soybean phenological stages. J. Econ. Entomol. 93:707-712.

Borrell, A. K., Mullet, J. E., George-Jaeggli, B., Oosterom, E. J. V., Hammer, G. L., Klein, P. E., and Jordan, D. R. 2014. Drought adaptation of staygreen sorghum is associated with canopy development, leaf anatomy, root growth, and water uptake. J. Exp. Bot. doi:10.1093/jxb/eru232.

Boudreaux, J., and Griffin, J. L. 2011. Application timing of harvest aid herbicides affects soybean harvest and yield. Weed Technol. 25:38-43.

Boudreaux, J. M., Griffin, J. L., Leonard, B. R., Schneider, R. W., and Salassi, M. E. 2010. Value of paraquat harvest aid in soybean IPM programs. Proc. South. Weed Sci. Soc. 63:118.

Dale, J. L., and Walters, H. J. 1985. Soybean bud proliferation of un-known etiology in Arkansas. Plant Dis. 69:811.

Daugherty, D. M., Nevstady, M. H., Gehrke, D. W., Cavanah, L. E., Williams, L. F., and Green, D. E. 1964. An evaluation of damage to soybeans by brown and green stink bugs. J. Econ. Entomol. 57:719-722.

Egli, D. B., and Bruening, W. P. 2006. Depodding causes green-stem syndrome in soybean. Crop Manage. doi:10.1094/CM-2006-0104-01-RS

Favero, F., and Lana, M. C. 2104. Reduction of green stem and leaf retention in soybean through greater nitrogen availability from seed treatment. Rev. Bras. Cienc. Solo 38:1432-1438.
Fehr, W. R., Caviness, C. E., Burmood, D. T., and Pennington, J. S. 1971. Stage of development descriptions for soybeans, Glycine max (L.) Merrill. Crop Sci. 11:929-931.

Formento, A. N., and de Souza, J. 2009. Detection of green stem disorder in Entre Rios, Argentina. J. Plant Pathol. 91:231-240.

Fujii, K., Kato, S., Sayama, T., Tanaka, Y., Nakazaki, T., Ishimoto, M., and Shiraiwa, T. 2015. Stability verification of the effects of stem determination and earliness of flowering on green stem disorder of soybean against genetic background and environment. Plant Prod. Sci. 18:166-179.

Greene, J., and Davis, J. 2015. Stink bugs. Page146-149 in: Compendium of Soybean Diseases and Pests. G. L. Hartman, et al., eds. American Phytopathological Society, St. Paul, MN.

Gwathmey, C. O., and Hall, A. E. 1992. Adaptation of midseason drought of cowpea genotypes with contrasting senescence traits. Crop Sci. 32:773778.

Hill, C. B., Bowen, C. R., and Hartman, G. L. 2013. Effect of fungicide application and cultivar on soybean green stem disorder. Plant Dis. 97:1212-1220

Hill, C. B., Hartman, G. L., Esgar, R., and Hobbs, H. A. 2006. Field evaluation of green stem disorder in soybean cultivars. Crop Sci. 46:879-885.

Hobbs, H. A., Hill, C. B., Grau, C. R., Koval, N. C., Wang, Y., Pedersen, W. L., Domier, L. L., and Hartman, G. L. 2006. Green stem disorder of soybean. Plant Dis. 90:513-518.

Holshouser, D. 2009. Green stem syndrome in soybean. Coop. Ext. Pub. 29121430, Virginia Polytech. Inst. and State Univ. https://pubs.ext.vt.edu/2912/2912-1430/2912-1430.html.

Isobe, K., Kurose, T., Sasaki, Y., Someya, T., Terasawa, A., Higo, M., and Torigoe, Y. 2014. Effects of early sowing cultivation on yield and occurrence of delayed stem senescence in several soybean cultivars in south Kanto. Jpn. J. Crop Sci. 83:195-202.

Kumudini, S., Pallikonda, P., and Steele, C. 2007. Photoperiod and E-genes influence the duration of the reproductive phase in soybean. Crop Sci. 47:1510-1517.

Leonard, B. R., Boquet, D., Padgett, B., Davis, J. A., Schneider, R., Griffin, J. L., Valverde, A., and Levy, R. J. J. 2011. Soybean green plant malady contributing factors and mitigation. La. Agric. 54:32-24.

Luquez, V., and Guiamet, J. 2000. Effects of the "Stay Green" genotype GGd1d1d2d 2 on leaf gas exchange, dry matter accumulation and seed yield in soybean (Glycine max L. Merr.). Ann. Bot. 87:313-318.

Mochizuki, A., Shiraiwa, T., Nakagawa, H., and Horie, T. 2005. The effect of temperature during the reproductive period on development of reproductive organs and the occurrence of delayed stem senescence in soybean. Jpn. J. Crop Sci. 74:339-343.

Padgett, G. B., Boquet, D., Schneider, R. W., and Purvis, M. 2010. The influence of fungicides, herbicides, and water stress and their interactions on green bean syndrome in soybean. Proc. South. Soybean Dis. Workers.

Rabedeaux, P. F., Gaska, J. M., Kurtzweil, N. C., and Grau, C. R. 2005. Seasonal progression and agronomic impact of Tobacco streak virus on soybean in Wisconsin. Plant Dis. 89:391-396. 
Rock, C., and Sun, X. 2006. Crosstalk between ABA and auxin signaling pathways in roots of Arabidopsis thaliana (L.) Heynh. Planta 222:98-106.

Samet, J., and Sinclair, T. 1980. Leaf senescence and abscisic acid in leaves of field-grown soybean. Plant Physiol. 66:1164-1168.

Sato, J., Shiraiwa, T., Sakashita, M., Tsujimoto, Y., and Yoshida, R. 2007. The occurrence of delayed stem senescence in relation to trans-zeatin riboside level in the xylem exudate in soybeans grown under excess-wet and drought soil conditions. Plant Prod. Sci. 10:460-467.

Schneider, R. W., Padgett, G. B., Boquet, D. J., and Valverde, R. A. 2010. Factors affecting the development of the green stem malady in soybean. Phytopathology 100:S115.
Schwenk, F. W., and Nickell, C. D. 1980. Soybean green stem caused by bean pod mottle virus. Plant Dis. 64:863-865.

Shaner, D. 2006. An overview of glyphosate mode of action: Why is it such a great herbicide? Proc. 2006 North Central Weed Sci. Soc. 61:94.

Thomas, H., and Ougham, H. 2014. The stay-green trait. J. Exp. Bot. doi: $10.1093 / \mathrm{jxb} / \mathrm{eru} 037$.

Wang, A., Li, Y., and Zhang, C. 2012. QTL mapping for stay-green in maize (Zea mays). Can. J. Plant Sci. 92:249-256.

Yamada, T., Shimada, S., Hajika, M., Hirata, K., Takahashi, K., Nagaya, T., Hamaguchi, H., Maekawa, T., Sayama, T., Hayashi, T., Ishimoto, M., and Tanaka, J. 2014. Major QTLs associated with green stem disorder insensitivity of soybean (Glycine $\max$ (L.) Merr.). Breeding Sci. 64:331338. 